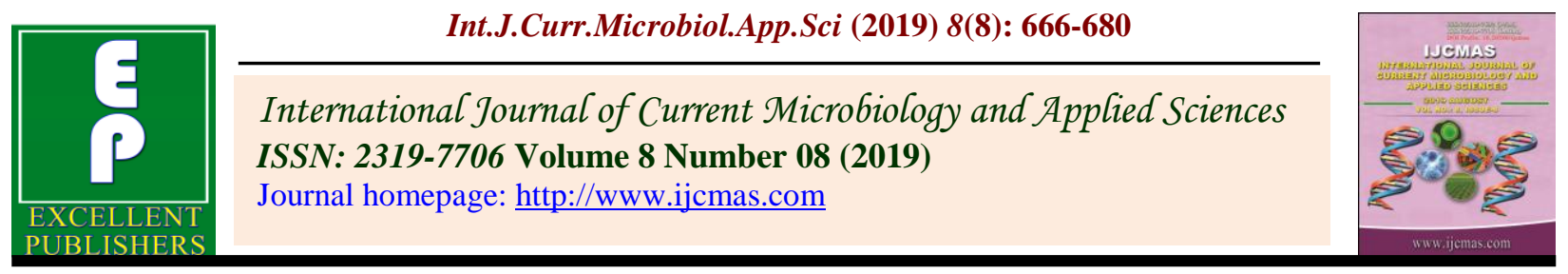

\title{
Clinical Study on Changes in Biophysical Dynamics of Rumen in Cattle Suffering from Small Bowel Intussusception
}

\author{
Jagdeep Singh Mann*, Ashok Kumar, Hansraj Bharadwaj and Shashi Kant Mahajan \\ Department of Veterinary Surgery and Radiology, Shere-e-Kashmir University of Agricultural \\ Sciences and Technology, R.S. Pura, Jammu - 181102, India \\ *Corresponding author
}

\section{A B S T R A C T}

The present study was conducted on thirty cattle suffering from small bowel intussusception presented at the institutional veterinary hospital. The animals were divided into three equal groups depending upon the duration of intussusception since the first signs of colic appear viz. Group I $(n=10)$ (since 48 hours), Group II $(n=10)$ ( $>48$ hours to 120 hours and Group III $(n=10)$ (120 hours to

\section{Keywords}

Intussusception, Rumen fluid, Microflora

Article Info

Accepted:

07 July 2019

Available Online:

10 August 2019
192 hours). The data from these animals was compared with the values obtained from the 6 healthy animals (control group) from the organised farm. Colour of rumen fluid was normal in all the animals of group I and II and was normal in $70 \%$ of group III cases. Consistency of rumen fluid was watery in $60 \%, 80 \%$ and $100 \%$ of group I, II and III animals respectively. Odour of rumen fluid was normal (Aromatic) in all the animals of group I, whereas, it was abnormal in $30 \%$ animals of group III. Sedimentation activity test (SAT) values were significantly decreased in all the groups of diseased animal as compared to control group. Values of $\mathrm{pH}$ varied non significantly in all the groups of diseased animals as compare to control group. MBRT values of all the groups of diseased animals were significantly higher from control group animals. Rumen fluid chloride varied significantly amongst all the groups. Cellulose digestion test (CDT) time was prolonged in $70 \%$, $80 \%$ and $90 \%$ cases of group I, II and III respectively. Protozoan motility of all the groups of diseased animals was significantly low as compare to control group. Seasonal variations were also reported in rumen fluid parameters, cases admitted in rainy season have better microfloral activity. Altered microflora was managed by administration of combination of prebiotics, probiotics and synbiotics. All the parameters of rumen fluid were recorded at the time of presentation of case and sampling was repeated 4 days after post surgical treatment.

\section{Introduction}

The rumen is unique to the ruminant species. The digestion of feed stuff within this chamber is accomplished by microbial fermentation. The rumen acts as a dynamic culture system harvesting a broad diversity of microbial populations mainly protozoa, bacteria and fungi (Smith and Jones, 2009). The end products of the rumen bacterial fermentations, the volatile fatty acids (VFAs) supply the major source of energy to ruminants (Rosenberger et al., 1979; Moran, 2005). The well-being of the ruminants largely depends upon the undisturbed functioning of the rumen microflora. In acute intestinal intussusception of small intestine oral segment of intestine dilates and fills with fluid and refluxes into the rumen leading to decrease in its buffering capacity. As in such instances, the rumen becomes distended with fluid due to the reflux from abomasum which leads to 
further accumulation of fluid in the rumen, thereby leading to changes in its biophysical environment (Radostits et al., 2009). So the present study was planned to investigate the biophysical dynamics of ruminal fluid in cattle suffering from small bowel intussusception.

\section{Materials and Methods}

The present study was conducted on 30 cattle admitted to the department of Teaching Veterinary Clinical Complex (TVCC), Faculty of Veterinary Sciences and Animal Husbandry, Sher-e-Kashmir University of Agricultural Sciences and Technology, R.S. Pura, Jammu with confirmed cases of small bowel intussusception on laparotomy.

The animals were divided into three equal groups depending upon the duration of intussusception since the first signs of colic appear viz. Animals showing signs of colic since 48 hours, more than 48 to $120 \mathrm{hrs}$ and more than 120 to 192 hours were assigned groups I, II and III, respectively (also depicted in table 1).

The data from these animals was compared with the values obtained from the 6 healthy animals (control group) from the organised farm. For the study of seasonal variation animals were divided into 2 groups viz. group A $(n=10)$ (cases admitted in rainy season) and group $B(n=20)$ (cases admitted in winters).

\section{Physiological parameters}

Rumen motility

Auscultation of rumen

\section{Parameters of rumen fluid}

Approximately $50 \mathrm{ml}$ of rumen fluid sample was collected from all the thirty diseased animals as well as from control group animals $(\mathrm{n}=6)$. The various parameters viz.

\section{Physical parameters}

The 1) colour, 2) consistency and 3) odour of the rumen fluid obtained were evaluated subjectively at the time of collection.

Sedimentation activity test was carried out by pouring a sample of rumen fluid in to a test tube and allowed to stand. The time (minutes) was measured for completion of sedimentation of fine particles and flotation of coarse solid particles (Asrat et al., 2015).

\section{Chemical parameters}

Hydrogen ion concentration $(\mathrm{pH})$ of rumen liquor was determined immediately after collection of sample by using narrow range pH papers (Jackson and Cockcroft, 2002).

Methylene blue reduction time was estimated by transferring $20 \mathrm{ml}$ of rumen fluid in to a sterile glass blood collection tube and mixing with $1 \mathrm{ml}$ of $0.03 \%$ methylene blue (Jackson and Cockcroft, 2002; Fubini and Ducharme, 2004). The mixed sample with test tube was allowed to stand at room temperature. The time in minutes needed for the colour of the mixture to change was recorded as methylene blue reduction time (Boodur et al., 2010) and the colour compared with a control of rumen fluid only (Jackson and Cockcroft, 2002).

Cellulose digestion test was carried out as per method described by (Rosenberger et al., 1979). The test tube was filled with $10 \mathrm{ml}$ of rumen fluid and $0.3 \mathrm{ml}$ of $16 \%$ glucose was added. A cotton (cellulose) thread was weighted with a glass bead at the lower end.

The glass bead was hung in to the tube containing rumen liquor so that its portion immersed in to fluid and fine end of thread fixed at the rim with a matter snipped. It was incubated at $39^{\circ} \mathrm{C}$ and the time in hours required for the thread to be snapped and bead 
dropped at the bottom of the tube was recorded (Rosenberger et al., 1979; Asrat et al., 2015). Fully active rumen fluid will digest the cellulose within 48-54 hours (Rosenberger et al., 1979). Rumen liquor was centrifuged and then filtered to collect clear supernatant.

Rumen fluid chloride was estimated by colorimetric method (Hussain et al., 2015).

\section{Microscopic protozoan activity}

Protozoal activity was examined by placing one drop of fresh ruminal fluid on a prewarmed microscope slide and a cover slip was placed. It was examined under low power objective of magnifying microscope (Rosenberger et al., 1979). Protozoan motility was graded in five categories: ++++ Good : $>10$ mobile protozoa per field; +++ fair: 6-9 mobile protozoa per field; ++ subnormal: $3-5$ mobile protozoa per field; + very low: 1-3 mobile protozoa per field and nil for zero protozoan per field (Rosenberger et al., 1979).

\section{Clinical management of altered microflora}

Along with routine treatment altered microflora was managed by administration of combination of prebiotics, probiotics and synbiotics containing Saccharomyces cerevisiae 50 billion CFU, Lactobacillus sporogenes 40 million CFU, Aspergillus oryzae 40 million CFU, Biotin $10 \mathrm{mg}$, DLMethionine $2 \mathrm{~g}$, Zinc sulphate $400 \mathrm{mg}$, Cobalt sulphate $80 \mathrm{mg}$, copper sulphate $200 \mathrm{mg}$, Fructo- oligosachharide $500 \mathrm{mg}$ per day p.o for 4 days.

Post treatment rumen fluid samples were taken after 4 days of treatment and evaluated. Sampling was feasible only in 18 (6 from each group) animals due to various reasons like death of animal, non-compliance by owner. Along with collection of samples rumen motility was also accessed.

\section{Statistical analysis}

The data generated was statistically analysed by using one-way ANOVA and t- test using SPSS (Statistical Package for Social Sciences) software (version 16.0-SPSS Inc.).

\section{Results and Discussion}

\section{Rumen motility}

Mean \pm S.E. values of rumen motility in all the groups of diseased animals was found to be significantly low than control group animals (Table 2). Statistically rumen motility has not shown variation among diseased group animals. Zavitz and Zavitz (1960) and Smart et al., (1977) observed complete absence of rumen motility in animals suffering from intussusception. Whereas, Abutarbush and Naylor (2006), Karapinar and Kom (2007) and Steiner et al., (2008) observed markedly reduced rumen motility in intestinal obstruction and sometimes rumen contractions persist but amplitude is decreased throughout the course of disease. Smith and Jones (2009) stated if pain is severe in obstruction, forestomach atony may occur. Reduced motility might be attributed to variable degree of distension in intussusception. The excessive distension by bulky ingesta may precipitate continuous activation of the epithelial receptors in forestomach lining leading to ruminal stasis, as it has a reflex inhibitory effect on primary cycle motility (Leek, 1983).

\section{Auscultation and percussion of rumen}

On auscultation of rumen, no ruminal contractions were observed in $17(56.67 \%)$ cases over 3 minutes, contractions were normal (3/ 2 mins) in $3(10 \%)$ cases and was reduced in remaining $10(33.33 \%)$ animals, wherever contractions were present strength and amplitude was less as compared to control group animals. 
Feeding of $83.33 \%$ of animals was consists only roughage and remaining $16.67 \%$ animals roughage along with concentrates. Findings of auscultation were found parallel with findings of rumen motility. Rasping or friction sounds of varying duration (from 5- 7 seconds) were observed in $9(30 \%)$ cases however, no ruminal sounds were detected in remaining 21 (70\%) cases. On simultaneous percussion with auscultation, ping sound detected in $3(10 \%)$ cases where rumen was atonic. In control group, strong contractions with rustling or crackling sounds were observed and in all the six cases three contractions per two minutes were noticed. Tharwat (2011) on abdominal auscultation in cows $(n=8)$, calves $(n=6)$ and buffaloes $(n=4)$ with intestinal obstruction heard no ruminal contractions over $3 \mathrm{~min}$ in eleven animals out of 18. Abutarbush and Radostits (2004) heard a dull, low-pitched, "pung" sound was on percussion over the left paralumbar fossa. Smith and Jones (2009) stated sounds represent the friction of fibrous ingesta rubbing against the ruminal wall as the ruminal sacs contract and mix their contents. In healthy cattle on a roughage diet, the normal rustling sound is prominent and prolonged with each contraction cycle. Radostits et al., (2009) stated cause of ping on percussion is the atonic rumen. Results are also depicted in Table 3.

\section{Physical parameters of rumen fluid}

\section{Colour of rumen fluid}

Colour of rumen fluid was greenish in 13 (43.34\%) cases, yellowish to yellow brown in $12(40 \%)$ cases, darker greenish black in 4 (13.34\%) cases and milky white in 1 (3.34\%) case. In control group colour varied from greenish to yellowish brown (Table 4). Colour was yellowish to yellowish brown in animals those were given paddy/ wheat straw or wheat bran findings are similar to (Rosenberger et al., 1979; Smith and Jones, 2009; Asrat et al.,
2015). In $13.34 \%$ of animals colour of rumen fluid was darker greenish black it may be due to prolonged stasis of rumen (Navarre et al., 2012). Milky grey colour was reported only in one animal, which was having history of feeding wheat bran and $\mathrm{pH}$ of rumen fluid in this case was 5.5 similar findings were also reported by (Jasmin et al., 2011).

\section{Consistency of rumen fluid}

Consistency in 7 (23.34\%) cases was slightly viscous which was comparable with control group animals. Consistency was watery in remaining 23 (76.67\%) cases (Table 5) and does not seem to be varied with duration of intussusception. Watery consistency is indicative of inactive bacteria and protozoa (Radostits et al., 2009). Slightly viscous consistency has been reported to be normal in healthy cattle (Rosenberger et al., 1979; Radostits et al., 2009; Smith and Jones, 2009).

In cases where consistency was slightly viscous there was history of prolonged adipsia (in some of the cases) and severe dehydration was also reported, however, comparatively active microflora was also noticed in some of the cases with slightly viscous consistency.

\section{Odour of rumen fluid}

Odour of rumen fluid was normal/ aromatic in $27(90 \%)$ cases and was comparable with control group animals. Abnormal odour was observed only in cases from group III (Table $6)$. Odour of rumen fluid was not varied with the duration of intussusception in majority of the cases, however, reason is unknown. Odour was acidic in 2 cases where $\mathrm{pH}$ was found to be acidic and slightly ammonical in 1 case where $\mathrm{pH}$ was 10 (alkaline) abnormal findings were similar to findings of Mohan et al., (2015) in acid and alkaline indigestion in buffaloes. Further studies are needed to verify such results. 


\section{Sedimentation Activity Test (SAT)}

Mean \pm S.E. values of SAT were significantly decreased in all the groups of diseased animals as compare to control group. However, values of SAT within groups of diseased animals (I, II and III) varied non significantly. The results of the present study with very rapid sedimentation (Fig. 1) to no floatation in most of the cases could be related to the prolonged anorexia, reflux of abomasal fluid into rumen and inactive microflora, findings were significantly different from control group animals. Sedimentation activity test directly determine the microfloral activity (Asrat et al., 2015). Watery fluid rendered inactive by starvation, a feed without nutritional value or by inappetence sediments rapidly and floatation is absent or retarded (Smith and Jones, 2009). Inactive microflora results in rapid sedimentation with little floating material (Jackson and Cockcroft, 2002). Findings indicated inactive microflora of rumen in intussusception (Table 7).

\section{Chemical parameters}

The mean \pm S.E. values of chemical parameters are presented in Table 8 .

\section{Hydrogen ion concentration (pH)}

Mean \pm S.E. values of $\mathrm{pH}$ did not differ significantly from control group animals. However, values were slightly higher than normal physiological $\mathrm{pH}$. Findings were similar to Papadopolous et al., (1985 b) they observed that the $\mathrm{pH}$ of rumen fluid was either neutral or slightly towards alkaline side in experimental intestinal obstruction of cattle and they said it was probably due to the large buffering capacity of saliva. Smith and Jones (2009) stated an alkaline ruminal fluid $\mathrm{pH}$ occurs most commonly when microbial fermentation is reduced while the animal continues to ingest saliva, a ruminal fluid $\mathrm{pH}$ between 7 and 7.5 is found with prolonged anorexia, microfloral inactivity caused by poorly digestible roughage. The low rate of fermentation does not generate enough acid to neutralize the alkaline $\mathrm{pH}$ of the saliva.

\section{Methylene Blue Reduction Test (MBRT)}

Mean \pm S.E. values of MBRT of all the groups of diseased animals were significantly higher from control group animals. Values was significantly higher in group III than group I and group II, however values of group I and II varied non significantly among themselves. MBRT of the rumen fluid in most of the cases required more than 3 min (delayed clearing). Overall, MBRT in animals suffering from intussusception was greatly increased which was indicative of reduction in number of anaerobes (Fig. 2). Fubini and Ducharme (2004) opined that delayed clearing of the dye indicated diminished anaerobic bacterial activity. The results of present study could be related to as in acute intestinal intussusception of small intestine oral segment of intestine dilates and fills with fluid and refluxes into the rumen leading to decrease in its buffering capacity.

As in such instances, the rumen becomes distended with fluid due to the reflux from abomasum leads to further accumulation of fluid in the rumen, thereby leading to changes in its biophysical environment (Radostits et al., 2009). Along with this prolonged anorexia, ruminal stasis and exclusive feeding of paddy straw (Randhawa et al., 1992) could also be the reasons for alteration in biophysical parameters of rumen fluid.

\section{Rumen fluid chloride}

Values of rumen fluid chloride varied significantly amongst all the groups and found to be highest in group III animals followed by group II and group I. 
Table.1 Groups of study

\begin{tabular}{|l|c|c|c|c|}
\hline GROUPS & GROUP I & GROUP II & GROUP III & Control \\
\hline $\begin{array}{l}\text { Duration of colic } \\
\text { (hours) }\end{array}$ & $\leq 48$ & $>48$ to 120 & $>120$ to 192 & - \\
\hline No. of animals & 10 & 10 & 10 & 6 \\
\hline
\end{tabular}

Table.2 Rumen motility recorded in healthy control animals and diseased animals suffering from intussusception (Mean \pm S.E)

\begin{tabular}{|l|l|l|l|l|l|}
\hline Parameter & $\begin{array}{l}\text { Control } \\
\text { group }(\mathbf{n}=6)\end{array}$ & $\begin{array}{l}\text { Group I } \\
(\mathbf{n = 1 0})\end{array}$ & $\begin{array}{l}\text { Group II } \\
(\mathbf{n = 1 0})\end{array}$ & $\begin{array}{l}\text { Group } \\
\text { III } \\
(\mathbf{n = 1 0})\end{array}$ & $\begin{array}{l}\text { Reference } \\
\text { values }\end{array}$ \\
\hline $\begin{array}{l}\text { Rumen } \\
\text { motility }\end{array}$ & $3.00 \pm 00^{\mathrm{a}}$ & $1.2 \pm 0.39^{\mathrm{b}}$ & $0.7 \pm 0.34^{\mathrm{b}}$ & $0.4 \pm 0.22^{\mathrm{b}}$ & $(3 / 2 \mathrm{~min})$ \\
\hline
\end{tabular}

Means bearing different superscripts differ significantly $(\mathrm{p}<0.05)$.

Table.3 Auscultation and percussion of rumen

\begin{tabular}{|c|c|c|c|}
\hline \multirow{2}{*}{\multicolumn{2}{|c|}{ Auscultation and percussion of rumen }} & \multirow{2}{*}{\multicolumn{2}{|c|}{ No. of animals }} \\
\hline & & & \\
\hline \multirow{3}{*}{ Rumen contractions } & Absent & $17(5667 \%)$ & 00 \\
\hline & Normal (3/2 minutes) & $03(10 \%)$ & $06(100 \%)$ \\
\hline & Decreased & $10(33.33 \%)$ & 00 \\
\hline \multirow[t]{2}{*}{ Friction sounds } & Present & $09(30 \%)$ & $06(100 \%)$ \\
\hline & Absent & $21(70 \%)$ & 00 \\
\hline \multirow[t]{2}{*}{ Ping sound } & Present & $03(10 \%)$ & 00 \\
\hline & Absent & $27(90 \%)$ & $06(100 \%)$ \\
\hline
\end{tabular}

Table.4 Colour of rumen fluid in control group animals and animals suffering from intussusception

\begin{tabular}{|c|c|c|c|c|c|}
\hline $\begin{array}{l}\text { Colour of } \\
\text { rumen fluid }\end{array}$ & $\begin{array}{c}\text { Control } \\
\text { group } \\
(n=6)\end{array}$ & $\begin{array}{c}\text { Group I } \\
(n=10)\end{array}$ & $\begin{array}{c}\text { Group II } \\
(n=10)\end{array}$ & $\begin{array}{l}\text { Group III } \\
(\mathbf{n}=\mathbf{1 0})\end{array}$ & $\begin{array}{l}\text { TOTAL } \\
(n=30)\end{array}$ \\
\hline Greenish & 05 & 04 & 05 & 05 & $14(46.67 \%)$ \\
\hline Yellowish & 01 & 06 & 05 & 01 & $12(40 \%)$ \\
\hline $\begin{array}{l}\text { Darker } \\
\text { greenish }\end{array}$ & 00 & 00 & 00 & 03 & $03(10 \%)$ \\
\hline Milky grey & 00 & 00 & 00 & 01 & $01(3.33 \%)$ \\
\hline
\end{tabular}


Table.5 Consistency of rumen fluid in control group animals and animals suffering from intussusceptions

\begin{tabular}{|c|c|c|c|c|c|}
\hline $\begin{array}{l}\text { Consistency of } \\
\text { rumen fluid }\end{array}$ & $\begin{array}{c}\text { Control } \\
\text { group }(n=6)\end{array}$ & $\begin{array}{c}\text { Group I } \\
(n=10)\end{array}$ & $\begin{array}{c}\text { Group II } \\
(n=10)\end{array}$ & $\begin{array}{c}\text { Group III } \\
(\mathbf{n}=\mathbf{1 0})\end{array}$ & TOTAL \\
\hline Slightly viscous & 06 & 04 & 02 & 00 & $06(20 \%)$ \\
\hline Watery & 00 & 06 & 08 & 10 & $24(80 \%)$ \\
\hline Very viscous & 00 & 00 & 00 & 00 & 00 \\
\hline
\end{tabular}

Table.6 Odour of rumen fluid in control group animals and animals suffering from intussusception

\begin{tabular}{|l|l|l|l|l|l|}
\hline $\begin{array}{l}\text { Odour of } \\
\text { rumen fluid }\end{array}$ & $\begin{array}{l}\text { Control } \\
\text { group } \\
(\mathbf{n = 6})\end{array}$ & $\begin{array}{l}\text { Group I } \\
(\mathbf{n = 1 0})\end{array}$ & $\begin{array}{l}\text { Group II } \\
(\mathbf{n = 1 0})\end{array}$ & $\begin{array}{l}\text { Group } \\
\text { III } \\
(\mathbf{n = 1 0})\end{array}$ & $\begin{array}{l}\text { Total } \\
(\mathbf{N = 3 0})\end{array}$ \\
\hline Aromatic & 06 & 10 & 10 & 07 & $\mathbf{2 7}(\mathbf{9 0 \%})$ \\
\hline $\begin{array}{l}\text { Slightly } \\
\text { ammonical }\end{array}$ & 00 & 00 & 00 & 02 & $\mathbf{0 2}(\mathbf{6 . 6 7 \% )})$ \\
\hline Acidic & 00 & 00 & 00 & 01 & $\mathbf{1}(\mathbf{3 . 3 3 \%})$ \\
\hline Putrid & 00 & 00 & 00 & 00 & $\mathbf{0 0}$ \\
\hline $\begin{array}{l}\text { Normal odour- (Aromatic) } \\
\text { Abnormal odour-(Slightly ammonical, Acidic, putrid) }\end{array}$ &
\end{tabular}

Table.7 Sedimentation activity of rumen fluid in control group animals and animals suffering from intussusceptions (Mean \pm S.E.) values

\begin{tabular}{|l|l|}
\hline GROUP & SAT \\
\hline CONTROL & $5.34 \pm 0.49^{\mathrm{a}}$ \\
\hline GROUP I & $3.1 \pm 0.69^{\mathrm{b}}$ \\
\hline GROUP II & $2.4 \pm 0.58^{\mathrm{b}}$ \\
\hline GROUP III & $1.6 \pm 0.73^{\mathrm{b}}$ \\
\hline & Reference value $\mathbf{( 4 - 8} \mathbf{~ m i n})$ \\
\hline
\end{tabular}

Means bearing different superscripts differ significantly $(\mathrm{p}<0.05)$

Table.8 Chemical parameters of rumen fluid recorded in control group animals and animals suffering from intussusceptions (Mean \pm S.E)

\begin{tabular}{|l|l|l|l|l|l|}
\hline Parameter & Control & Group I & Group II & Group III & Reference value \\
\hline Ph & $7.0 \pm 0.13^{\mathrm{a}}$ & $7.05 \pm 0.28^{\mathrm{a}}$ & $7.2 \pm 0.39^{\mathrm{a}}$ & $7.2 \pm 0.47^{\mathrm{a}}$ & $\mathbf{6 - 7}^{\mathrm{7}}$ \\
\hline MBRT & $5.0 \pm 0.78^{\mathrm{a}}$ & $14.7 \pm 1.81^{\mathrm{b}}$ & $21.2 \pm 2.05^{\mathrm{b}}$ & $30.80 \pm 3.04^{\mathrm{c}}$ & $\mathbf{3 - 6} \mathbf{~ m i n}$ \\
\hline $\begin{array}{l}\text { Rumen } \\
\text { chloride }\end{array}$ & $23.84 \pm 2.64^{\mathrm{a}}$ & $42.4 \pm 3.25^{\mathrm{b}}$ & $59.4 \pm 4.25^{\mathrm{c}}$ & $82.9 \pm 7.35^{\mathrm{d}}$ & $\mathbf{( 1 5 - 2 5} \mathbf{~ m m o l} / \mathbf{L})$ \\
\hline
\end{tabular}

Means bearing different superscripts differ significantly $(\mathrm{p}<0.05)$. 
Table.9 Cellulose digestion test of rumen fluid in control group animals and animals suffering from intussusceptions

\begin{tabular}{|l|c|c|}
\hline \multirow{2}{*}{ Group } & \multicolumn{2}{|c|}{ Cellulose digestion test (CDT) } \\
\cline { 2 - 3 } & Normal & Prolonged \\
\hline CONTROL $(\mathrm{n}=6)$ & 06 & 00 \\
\hline GROUP I $(\mathrm{n}=10)$ & 03 & 07 \\
\hline GROUP II $(\mathrm{n}=10)$ & 02 & 08 \\
\hline GROUP III $(\mathrm{n}=10)$ & 01 & 09 \\
\hline TOTAL $(\mathrm{n}=30)$ & $06(20 \%)$ & $24(80 \%)$ \\
\hline Normal CDT- $\mathbf{( 4 8 - 5 6} \mathbf{~ h r s )}$; Prolonged CDT- $(>\mathbf{5 6} \mathbf{~ h r s})$ \\
\hline
\end{tabular}

Table.10 Protozoan motility recorded in control group animals and animals suffering from intussusceptions (Mean \pm S.E) values

\begin{tabular}{|c|c|}
\hline GROUP & PROTOZOAN ACTIVITY \\
\hline CONTROL & $4.0 \pm 00^{\mathrm{a}}$ \\
\hline GROUP I & $1.6 \pm 0.56^{\mathrm{b}}$ \\
\hline GROUP II & $1.0 \pm 0.43^{b}$ \\
\hline GROUP III & $0.6 \pm 0.40^{b}$ \\
\hline & Reference value Good: (> 10/ field) $(++++)$ \\
\hline
\end{tabular}

Means bearing different superscripts differ significantly $(\mathrm{p}<0.05)$.

Table.11 Seasonal variations in rumen fluid parameters (Mean \pm S.E.) values

\begin{tabular}{|l|c|c|}
\hline Groups & $\begin{array}{c}\text { Cases in rainy season (A) } \\
(\mathbf{n = 1 0})\end{array}$ & $\begin{array}{c}\text { Cases in Winters }(\mathbf{B}) \\
(\mathbf{n}=\mathbf{2 0})\end{array}$ \\
\hline Parameters & $\mathbf{2 . 9} \pm \mathbf{3 . 1}$ & $\mathbf{0 . 1 5} \pm \mathbf{0 . 1} * *$ \\
\hline Protozoan Motility & $\mathbf{3 . 4} \pm \mathbf{0 . 7 1}$ & $\mathbf{1 . 8} \pm \mathbf{0 . 4 3}$ \\
\hline SAT & $\mathbf{1 6 . 7 \pm 2 . 5}$ & $\mathbf{2 5 . 0 \pm 2 . 1 5 ^ { * }}$ \\
\hline MBRT & $\mathbf{6 . 7 \pm 0 . 2 6}$ & $\mathbf{7 . 3} \pm \mathbf{0 . 2 8}$ \\
\hline Ph & &
\end{tabular}

**significant at $\mathrm{p}<0.01$ between the groups

*significant at $p<0.05$ between the groups

Table.12 Effect of probiotics on ruminal parameters in cattle (Mean \pm S.E) values.

(Total cases: $n=18$ )

\begin{tabular}{|l|l|l|l|}
\hline Parameter & Control group $(\mathbf{n}=6)$ & Pre-treatment group $(\mathbf{n = 1 8})$ & Post-treatment group $(\mathbf{n}=18)$ \\
\hline Protozoan Motility & $4.0 \pm 00^{\mathrm{b}}$ & $0.94 \pm 0.32^{\mathrm{a}}$ & $3.61 \pm 0.43^{\mathrm{b}}$ \\
\hline SAT & $5.33 \pm 0.49^{\mathrm{b}}$ & $2.44 \pm 0.49^{\mathrm{a}}$ & $5.33 \pm 0.49^{\mathrm{b}}$ \\
\hline MBRT & $5.0 \pm 0.78^{\mathrm{b}}$ & $22.05 \pm 2.64^{\mathrm{a}}$ & $5.31 \pm 0.32^{\mathrm{b}}$ \\
\hline Rumen fluid chloride & $26.17 \pm 2.44^{\mathrm{b}}$ & $59.11 \pm 4.50^{\mathrm{a}}$ & $23.08 \pm 0.43^{\mathrm{b}}$ \\
\hline pH & $7.0 \pm 0.13$ & $7.39 \pm 0.32^{\mathrm{a}}$ & $7.08 \pm 0.08$ \\
\hline Rumen motility & $3.0 \pm 00^{\mathrm{b}}$ & $1.05 \pm 0.29^{\mathrm{a}}$ & $2.56 \pm 0.15^{\mathrm{b}}$ \\
\hline
\end{tabular}

Means bearing different superscripts differ significantly $(\mathrm{p}<0.05)$. 
Table.13 Effect of probiotics on ruminal parameters in cattle (Mean \pm S.E) values

\begin{tabular}{|l|l|l|l|l|l|}
\hline Parameter & $\begin{array}{l}\text { Control } \\
\text { group }(\mathbf{n = 6})\end{array}$ & $\begin{array}{l}\text { Group I } \\
(\mathbf{n = 6})\end{array}$ & $\begin{array}{l}\text { Group II } \\
(\mathbf{n = 6})\end{array}$ & $\begin{array}{l}\text { Group III } \\
(\mathbf{n = 6})\end{array}$ & $\begin{array}{l}\text { Reference } \\
\text { values }\end{array}$ \\
\hline $\begin{array}{l}\text { Protozoan } \\
\text { Motility }\end{array}$ & $4.0 \pm 00$ & $3.83 \pm 0.17$ & $3.67 \pm 0.21$ & $3.33 \pm 0.33$ & $\begin{array}{l}>10 / \quad \text { field } \\
(++++)\end{array}$ \\
\hline SAT & $5.33 \pm 0.49^{\mathrm{a}}$ & $5.83 \pm 0.30^{\mathrm{a}}$ & $4.33 \pm 0.17^{\mathrm{b}}$ & $4.0 \pm 0.26^{\mathrm{b}}$ & $4-8 \mathrm{~min}$ \\
\hline MBRT & $5.0 \pm 0.77^{\mathrm{a}}$ & $4.09 \pm 0.26^{\mathrm{a}}$ & $5.29 \pm 0.31^{\mathrm{ab}}$ & $6.66 \pm 0.42^{\mathrm{b}}$ & $4-8 \mathrm{~min}$ \\
\hline $\begin{array}{l}\text { Rumen fluid } \\
\text { chloride }\end{array}$ & $23.84 \pm 2.64$ & $22.25 \pm 0.83$ & $22.50 \pm 0.66$ & $24.50 \pm 0.41$ & $\begin{array}{l}15- \\
\mathrm{mmol} / \mathrm{L}\end{array}$ \\
\hline pH & $7.0 \pm 0.13$ & $7.0 \pm 0.13$ & $7.08 \pm 0.08$ & $7.17 \pm 0.21$ & $6-7$ \\
\hline $\begin{array}{l}\text { Rumen } \\
\text { motility }\end{array}$ & $3.0 \pm 00$ & $2.83 \pm 0.41$ & $2.50 \pm 0.84$ & $2.33 \pm 0.52$ & $3 / 2 \mathrm{~min}$. \\
\hline
\end{tabular}

Means bearing different superscripts differ significantly $(\mathrm{p}<0.05)$.

Fig.1 Sedimentation of fine particles of rumen fluid

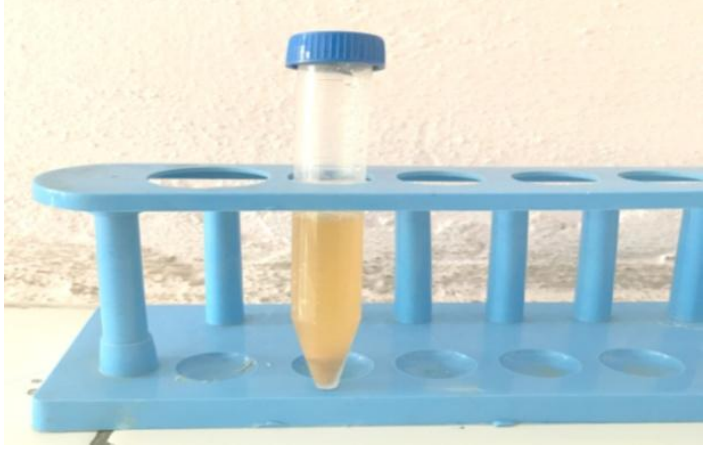

Fig.2 Partial Reduction (a, c) of methylene blue dye and comparison with the control (b, d) of rumen fluid

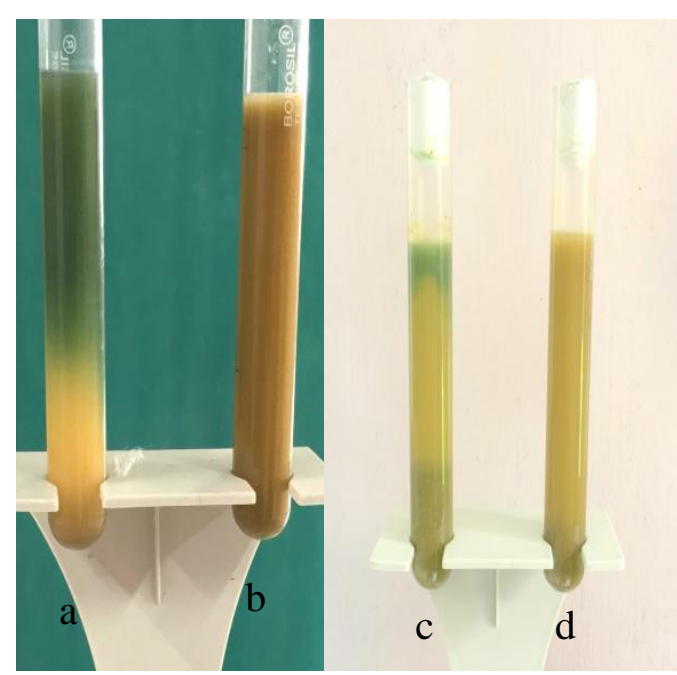


Fig.3 Microphotograhs of protozoans

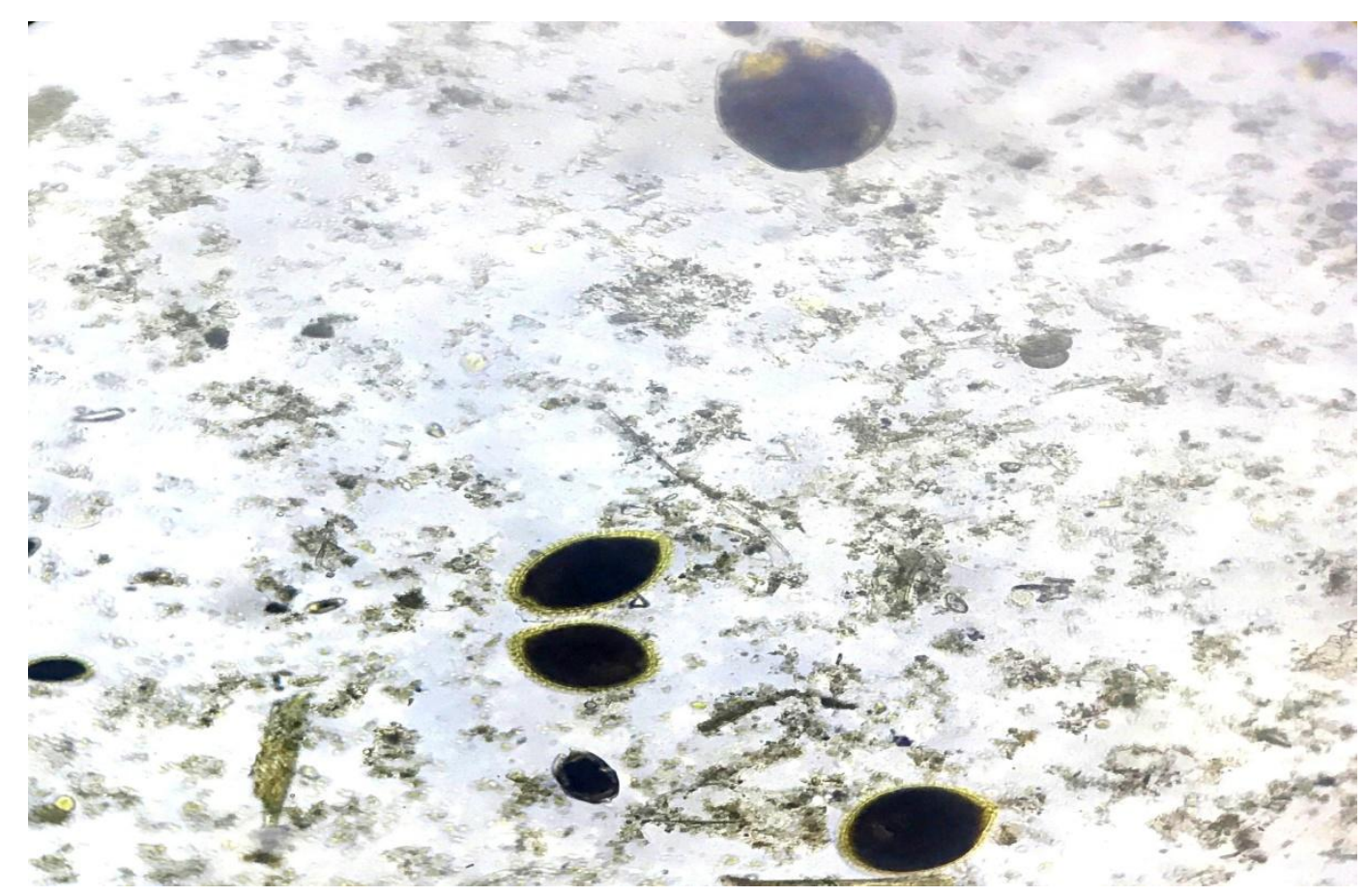

Findings were similar to Papadopolous et al., (1985b) they also observed increase in rumen fluid chloride level with increase in time of obstruction in experimental obstruction of intestine. Increase in rumen fluid chloride content in intussusception or other form of intestinal obstruction was also reported by previous authors (Avery et al., 1986; Abutarbush and Naylor, 2006; Imran et al., 2011; Hussain et al., 2015). The large amount of chloride in the rumino- reticulum following obstruction probably results from oral flow from the abomasum through the omasal canal rather than by diffusion from the blood across the mucosae (Hammond et al., 1964).

\section{Cellulose digestion test (CDT)}

Cellulose digestion test time was found to be increased in majority of the cases. It was found normal (within 48- 56 hours) only in 6 (20\%) cases (3 was from group I, 2 case was from group II and 1 from group 1) and was prolonged in rest of $24(80 \%)$ cases. In control group digestion of cellulose threads occurred in all the 6 animals within 48 hrs (Table 9). This indicates the presence of partial inactive ruminal flora in animals suffering from intussusception. Chakrabarti (2014) cellulose digestion time may become prolonged in ruminal disorders. Asrat et al., (2015) found that cellulose digestion test of the rumen fluid required greater than 56 hours in ruminal disorders which may be due to presence of partially inactive ruminal flora required for cellulose degradation.

\section{Protozoan activity}

Protozoan motility was drastically low in cases suffering from intussusception. It was found good (++++) only in 3 cases out total 30 cases ( 2 from group I), fair (+++) in 4 cases, subnormal $(++)$ in 3 cases, very low in 2 cases $(+)$, nil in remaining 18 cases. In control group motility was good in all the 6 cases (Table 10). Mean \pm S.E. values were significantly lower in group I, group II and group III in comparison to control group. However, values of protozoan activity 
between group I, group II and group III varied non-significant. So, protozoan motility though low in all the affected cases but still varied with the number of days since the animal was off fed. Similar findings were also reported by (Wani, 2015). Smart et al., (1977) also reported moderate numbers of dead protozoa in five year old Charolois bull suffering from intussusception. Microphotographs of protozoans shown in Figure 3.

\section{Seasonal variations in rumen fluid parameters}

Total of $10(33.33 \%)$ cases admitted in rainy season (group A) and $20(66.66 \%)$ cases in winter season (group B). In rainy season protozoan motility was seen even in chronic cases (group III), whereas, in winters (in the month of January and February) motility was found to be nil even in fresh (1 to 2 day old) cases. Highly significant increase was observed in protozoan motility of group A as compared to group B. MBRT was significantly higher in group B cases than group A. Sedimentation activity was rapid in group B than group A but the change was non-significant. $\mathrm{pH}$ in group $\mathrm{A}$ was within normal range but it was increased in group $\mathrm{B}$ but the change was non-significant. Digestion of cellulose thread was prolonged in all the cases of group B, whereas cellulose digestion occurred within 48 hours in group A animals (Table 11). Nottle (1956) has claimed to have found seasonal fluctuations in bacterial numbers. Moir (1950) observed marked seasonal fluctuations in the numbers of total organisms in grazing sheep. He also observed high level associated with the green grazing in winter, with a peak in the spring and a low level associated with the dry grazing. Orpin et al., (1985) observed $17 \%$ higher density of total cultured viable rumen bacteria in high arctic Svalbard reindeer in summers when food quality and availability is good than winters. In the present study it could be attributed to the more availability of green fodder in the region due to heavy rainfall in rainy season, due to this use of poor quality fodder (paddy straw, wheat straw) get decreased and there is better establishment of rumen microflora.

\section{Clinical management of altered microflora}

Post treatment rumen fluid samples (from 18 animals) 4 days after the treatment with combination of prebiotics, probiotics and synbiotics showed significant improvement from pre-treatment samples and results were comparable with control group (as depicted in Table 12). Samples showed increased protozoan motility and SAT. Decrease in MBRT, CDT and ruminal fluid chloride and $\mathrm{pH}$ of rumen fluid was within normal physiological range. Rumen motility of all the animals was also improved.

On comparison of post treatment samples group wise (group I, II and III) MBRT and SAT shown significant difference from pretreatment samples but results in both the groups were within normal physiological range hence no significance (Table 13). Colour of rumen fluid was greenish in 12 out of 18 and yellowish in 6 animals. Odour of rumen fluid was aromatic in all the 18 animals and consistency of rumen fluid was slightly viscous in all the 18 animals. These results were comparable with control group animals. Newbold et al., (1996) stated fungal feed supplements increase rumen bacterial numbers, this may be due to the respiratory activity of yeast which protects anaerobic rumen bacteria from damage by oxygen. Cellulose digesting and lactic acid utilizing bacteria are the most commonly enhanced ruminal bacteria groups by fungal supplementation (Callaway and Martin, 1997). Yeast culture stimulates the initial colonization on the plant fragments in the rumen allowing a more rapid commencement 
of fibre breakdown. A large increase in cellulolytic organisms has been found when yeast culture has been added to the diet (Harrison et al., 1988). In addition the possibility that yeast cells interact in the rumen with anaerobic fungi have been shown preferentially to colonize cellulose and hemicellulose, making the fibre more accessible to bacteria (Akin et al., 1983). The better control of rumen $\mathrm{pH}$ when yeast culture is fed may result from the inherent buffering capacity of yeast cells (Cartwright et al., 1986) or from reduced lactate accumulation (Williams et al., 1990). Increased ciliate protozoal population due to feeding of yeast culture to the animals is reported by (Maurya et al., 1993; Panda, 1994; Plata et al., 1994; Mathieu et al., 1996). The mode of action of Aspergillus oryzyae appears to be associated with its enzyme activity (Wallace and Newbold, 1995). Aspergillus oryzyae contains enzymes capable of the digestion of plant cell wall material. These are believed to include cellulase, xylanase, and phenolic acid esterases (Varel et al., 1993). Administration of prebiotic also results in increased numbers of beneficial intestinal flora (Schiffrin et al., 2007; Vulevic et al., 2008). Hamasalim (2016) stated synbiotic increases beneficial microorganisms in the gastrointestinal tract and improve intestinal architect and then promote intestine environment.

Biophysical dynamics of rumen such as protozoan motility, SAT were significantly low $(\mathrm{p}<0.05)$ and MBRT, rumen fluid chloride, CDT were significantly increased in cases suffering from intussusception as compare to control group animals and severity in alterations of biophysical dynamics increased with the chronicity of intussusception

Seasonal variations were also recorded in rumen fluid biophysical dynamics, protozoan motility was recorded good to fair in rainy season even in chronic cases, whereas subnormal to nil even in fresh cases that were admitted in winters.

Alterations in biophysical dynamics of rumen were managed by administration of combination of prebiotics, probiotics and synbiotics and on post treatment examination of rumen fluid there was significant improvement in rumen fluid parameters and values were comparable with control group animals.

\section{References}

Abutarbush, S. M. and Naylor, J. M. 2006. Obstruction of the small intestine by a trichobezoar in cattle: 15 cases (19922002). Journal of American Veterinary Medical Association, 229: 1627-1630.

Abutarbush, S. M. and Radostits, O. M. 2004. Obstruction of the small intestine caused by a hairball in 2 young beef calves. The Canadian Veterinary Journal, 45(4): 324.

Akin, D. E., Gordon, G. L. and Hogan, J. P. 1983. Rumen bacterial and fungal degradation of Digitaria pentzii grown with or without sulfur. Applied and Environmental Microbiology, 46: 738748.

Asrat, M., Manohar, M. and Melkamu, S. 2015. Clinical and Rumen Fluid Evaluation of Ruminal Disorders in Cattle. Journal of Animal Research, 5(2): 359-372.

Avery, T. B., Nagaraja, T. G. and Frey, R. A. 1986. Blood, urine and ruminal fluid changes associated with metabolic alkalosis induced by duodenal obstruction. American Journal of Veterinary Research, 47(4): 890-96.

Boodur, P., Sivaprakash, B.V., Kasaralivar, V. and Rand, D. D. 2010. Methylene blue reduction test in cattle affected with rumen impaction due to plastics. 
Journal of Indian Poly Vet, 11 (2): 184188.

Callaway, E. S. and Martin, S. A. 1997. Effects of a Saccharomyces cerevisiae culture on ruminal bacteria that utilize lactate and digest cellulose. The Journal of Dairy Science, 80: 2035-2044.

Cartwright, C. P., Juroszek, J. R., Beavan, M. J., Ruby, F. M. S., De Morais, S. M. F. and Rose, A. H. 1986. Ethanol dissipates the proton-motive force across the plasma membrane of Saccharomyces cerevisiae. Journal of General Microbiology, 132: 369-377

Chakrabarti, A. 2014. Textbook of Clinical Veterinary Medicine, $4^{\text {th }}$ Edition Kalyani publishers, Ludhiana. pp. 286353.

Fubini, S. L. and Ducharme, N. G. 2004. Farm Animal Surgery, $9^{\text {th }}$ Edition Saunders, Elsevier, pp. 161-240.

Hamasalim, H. J. 2016. Synbiotic as feed additives relating to animal health and performance. Advances in Microbiology, 6: 288-302.

Hammond, P. B., Dziuk, H. E., Usenik, E. A. and Stevens, C. E. 1964. Experimental intestinal obstruction in calves. Journal of Comparative Pathology, 74: 210222.

Harrison, G. A., Hemken, R.W., Dawson, K. A., Harmon, R.J. and Barker, K.B. 1988. Influence of addition of yeast culture supplement to diets of lactating cows on ruminal fermentation and microbial populations. Journal of Dairy Science, 71: 2967-2975.

Hussain, S. A., Uppal S. K., Randhawa, C. S. and Sood, N. K. 2015. Bovine intestinal obstruction: blood gas analysis, serum C-reactive protein and clinical, haematological and biochemical alterations. Journal of Applied Animal Research, 43(2): 224-230.

Imran, S., Tyagi, S. P., Kumar, A., Kumar, A., Sharma, A. and Shivali, S. 2011.
Usefulness and limitation of ultrasonography in the diagnosis of intestinal intussusception in cows. Veterinary Medicine International, 2011: $\quad 584387$. doi:10.4061/2011/584387.

Jackson P. G. G. and Cockcroft P. D. 2002. Clinical Examination of the Gastrointestinal System. $1^{\text {st }}$ Edition Blackwell Science Ltd., UK. pp 81-113. Jasmin, B. H., Modesto, R. B. and Schaer, T. P. 2011. Perioperative Ruminal $\mathrm{pH}$ Changes in Domestic Sheep (Ovis aries) housed in a biomedical research setting. American Association for Laboratory Animal Science, 50(1): 2732.

Karapinar, T. and Kom, M. 2007. Transrectal ultrasonographic diagnosis of the intussusception in a cow-case report special. Irish Veterinary Journal, 60: 7.

Leek, B. F. 1983. Clinical diseases of the rumen: A physiologist's view. Veterinary Record, 113: 10- 14.

Mathieu, F., Jouany, J. P., Senaud, J., Bohatier, J., Bertin, G. and Mercier, M. 1996. The effect of Saccharomyces cervisiae and Aspergillus oryzae on fermentation in the rumen of faunated and defaunated sheep: protozoal and probiotic interaction. Reproduction Nutrition Devlopment, 36:271-287.

Maurya, M. S., Singh, R., Pathak, N. N. and Kamra, D. N. 1993. Effect of feeding live yeast (Saccharomyces cervisiae) on nutrient digestibility in goats. In: Proceeding of Sixth Animal nutrition Research Workers Conference, Bhubaneswar, India, pp. 142.

Mohan, G. C., Kumar, A. C. and Naik, B. R. 2015. Effect of rumen fermentative disorders on physiological parameters in buffaloes. International Journal of Veterinary Sciences, 4(1): 10-14.

Moir, R. J. 1950. The seasonal variation in the ruminal microorganism of grazing 
sheep. Australian journal of agricultural research, 2(3): 322- 330.

Moran, J. 2005. How the rumen works. In: Tropical dairy farming: feeding management for small holder dairy farmers in the humid tropics. pp 41-49.

Navarre, C. B., Baird, A. N. and Pugh, D. G. 2012. Diseases of the Gastrointestinal System. In: Pugh, D.G. and Baird, A.N. (eds.). Sheep and Goat Medicine, $2^{\text {nd }}$ Edition Maryland Heights, MO: Elsevier-Saunders, pp. 71-105.

Newbold, C. J., Wallace, R. J. and McIntosh, F. M. 1996. Mode of action of the yeast Saccharomyces cerevisiae as a feed additive for ruminants. British Journal of Nutrition, 76: 249-261.

Nottle, M. C.1956.Ruminal flora studies in the sheep. VI. Diurnal, daily and seasonal fluctuations in the concentrations of 'free' rumen bacteria and in rumen $\mathrm{pH}$. Australian Journal of biological Sciences, 9: 593.

Orpin, C. G., Mathiesen, S. D., Greenwood, Y. and Blix, A. S. 1985. Seasonal changes in the ruminal microflora of the high- arctic Svalbard reindeer (Rangifer tarandus platyrhynchus). Applied and Environmental Microbiology, 50(1): 144-151.

Panda, A. K. 1994. Effect of yeast culture supplementation on performance and rumen fermentation in crossbred calves. M.V.Sc Thesis. Indian Veterinary Research Institute (Deemed University), Izatnagar, India.

Papadopolous, P., Raptopouloas, D., Dessiris, A., Tsimopoulos, G. and Roumpies, N. (1985b). Experimental Intestinal Obstruction in Cattle: Changes in blood, urine and rumen content chemistry. Zentralblatt Fur Veterinarmedizin Reihe A (Journal of Veterinary Medicine), 32: 276-288.

Plata, F., Mendoza, G. D., Barcena-Gama, J. R. and Gonzalez, S. 1994. Effect of yeast culture (Saccharomyces cervisiae) on neutral detergent fibre digestion in steers fed oat straw based diets. Animal Feed Science and Technology, 49: 203210.

Radostits, O.M., Gay, C.C., Hinchcliff, K.W. and Constable, P.D. 2009. Veterinary Medicine, A textbook of the diseases of cattle, horses, sheep, pigs and goats, $10^{\text {th }}$ Edition Saunders, Elsevier. pp. 189-375.

Randhawa, C. S., Randhawa, S. S. and Nuriyal, D. C. 1992. Experimental therapeutic trial in paddy-straw-induced alkaline indigestion in buffalo calves. Indian Journal of Animal Science, 62: 256-60.

Rosenberger, G., Dirksen, H. D. Grunder, E., Grunert, D., Krauze, M. and Mack, R. 1979. Clinical Examination of Cattle. $2^{\text {nd }}$ Edition Verky Paulparay, Berlin, Humburg, pp. 203-209.

Schiffrin, E. J., Kumar, V. B., Brown, C., Hager, C., Van't Hof, M. A. and Morley, J. E. 2007. Systemic inflammatory markers in older persons: The effect of oral nutritional supplementation with prebiotics. The Journal of Nutrition Health and Aging, 11: 475-479.

Smart, M. E., Fretz, P. B., Gudmundson, J. and Cymbaluk, N. 1977 Intussusception in a charolais bull. Canadian Veterinary Journal, 18: 244246.

Smith, P. B. and Jones, L. S. 2009. Diseases of alimentary tract. In: Smith, P.B.(ed.). Large Animal Internal Medicine $4^{\text {th }}$ Edition Mosby, Elsevier St. Louis, Missouri. pp. 779-892.

Steiner, S., Krametter-Frötscher, R. and Baumgartner, W. 2008. Obstruction of the intestine in adult cattle. Wiener Tierarztliche Monatsschrift, 95(7): 166176.

Tharwat, M. 2011. Diagnostic 
ultrasonography in cattle and buffaloes with intestinal obstruction. Journal of Agriculture and Veterinary Science, 4: 67-80.

Varel, V. H., Kreikemeier, K. K., Jung, H. J. G. and Hatfield, R. D. 1993. In vitro stimulation of forage fiber degradation by ruminal microorganisms with Aspergillus oryzae fermentation extract. Applied and Environmental Microbiology, 59: 3171-3176.

Vulevic, J., Drakoularakou, A., Yaqoob, P., Tzortzis, G. and Gibson, G. R. 2008. Modulation of the fecal microflora profile and immune function by a novel transgalactooligosaccharide mixture (BGOS) in healthy elderly volunteers. The American Journal of Clinical Nutrition, 88: 1438-1446.

Wallace, R. J. and Newbold, C. J. 1995. Microbial feed additives for ruminants. Fuller, R., Heidt, P. J., usch,V. and Waaij, D, V. (eds.). In: Probiotics: prospects of use in opportunistic infections. Institute for Microbiology and Biochemistry, Herborn-Dill, Germany. pp. 101-125.

Wani, R. A. 2015. Ultrasonographic studies on surgical affections of gastrointestinal tract in bovine. M.V.Sc thesis, Shere-Kashmir University of Agricultural Sciences and Technology, Jammu, India.

Williams, P. E. V., Walker, A. and MacRae, J. C. 1990. Rumen probiosis: The effects of addition of yeast culture (viable yeast (Saccharomyces cerevisiae) plus growth medium) on duodenal protein flow in wether sheep. The Proceedings of Nutrition Society, 49: 128A-128A.

Zavitz, S. and Zavitz, V. 1960. Rumenotomy \& intestinal anastomosis in a heifer. Canadian Veterinary Journal, 1(3): 115- 118.

\section{How to cite this article:}

Jagdeep Singh Mann, Ashok Kumar, Hansraj Bharadwaj and Shashi Kant Mahajan. 2019. Clinical Study on Changes in Biophysical Dynamics of Rumen in Cattle Suffering from Small Bowel Intussusception. Int.J.Curr.Microbiol.App.Sci. 8(08): 666-680. doi: https://doi.org/10.20546/ijcmas.2019.808.076 